\title{
HCV core antigen is an alternative marker to HCV RNA for evaluating active HCV infection: implications for improved diagnostic option in an era of affordable DAAs
}

\author{
Rujipat Wasitthankasem ${ }^{1}$, Preeyaporn Vichaiwattana ${ }^{1}$, Chompoonut Auphimai ${ }^{1}$, Nipaporn Siripon ${ }^{1}$, Sirapa \\ Klinfueng ${ }^{1}$, Pisit Tangkijvanich ${ }^{2}$, Sompong Vongpunsawad ${ }^{1}$, Yong Poovorawan ${ }^{\text {Corresp. }} 1$ \\ ${ }^{1}$ Center of Excellence in Clinical Virology, Faculty of Medicine, Chulalongkorn University, Bangkok, Thailand \\ 2 Research Unit of Hepatitis and Liver Cancer, Department of Biochemistry, Faculty of Medicine, Chulalongkorn University, Thailand \\ Corresponding Author: Yong Poovorawan \\ Email address: Yong.P@chula.ac.th
}

The core antigen of the hepatitis C virus (HCV Ag) presents an alternative marker to HCV RNA when screening patients for HCV viremia. This study sought to evaluate the utility of HCV Ag as a marker to assess active HCV infection in individuals residing in an HCV endemic area. From $298 \mathrm{HCV}$-seropositive individuals evaluated for the presence of antiHCV antibody, HCV Ag and HCV RNA, anti-HCV antibody was detected in 252 individuals (signal-to-cutoff ratios $\geq 5$ ), HCV RNA was detected in 222 individuals (88\%), and HCV Ag was reactive ( $\geq 3 \mathrm{fmol} / \mathrm{L}$ ) in 220 individuals (87\%). HCV genotype 1, 3, and 6 were identified. HCV Ag significantly correlated with HCV RNA irrespective of HCV genotype and/or HBV co-infection (log HCV RNA $=2.67+0.95[\log \mathrm{HCV} A g], \mathrm{R}^{2}=0.890, p<0.001$ ). To predict HCV viremia (HCV Ag $\geq 3 \mathrm{fmol} / \mathrm{L}$ ), the accuracy, sensitivity, specificity, positive predictive value, and negative predictive value were $99 \%, 99 \%, 100 \%, 100 \%$ and $97 \%$, respectively. We concluded that HCV Ag was a good surrogate marker for HCV RNA and could be used to diagnose active HCV infection in a resource-limited setting. As a result, a cost-effective strategy for screening and identifying active HCV carriers using HCV Ag detection would enable more patients access to efficacious and increasingly affordable direct-acting antivirals (DAAs) for the treatment of HCV infection. 


\section{HCV Core Antigen is an Alternative Marker to HCV RNA for Evaluating}

\section{Active HCV Infection: Implications for Improved Diagnostic Option in an}

\section{Era of Affordable DAAs}

4 Rujipat Wasitthankasem ${ }^{1}$, Preeyaporn Vichaiwattana ${ }^{1}$,Chompoonut Auphimai ${ }^{1}$,Nipaporn

5 Siripon $^{1}$, Sirapa Klinfueng ${ }^{1}$, Pisit Tangkijvanich ${ }^{2}$, Sompong Vongpunsawad ${ }^{1}$ and Yong

6 Poovorawan $^{1}$

$7{ }^{1}$ Center of Excellence in Clinical Virology, Faculty of Medicine, Chulalongkorn University,

8 Bangkok, Thailand

$9 \quad{ }^{2}$ Research Unit of Hepatitis and Liver Cancer, Department of Biochemistry, Faculty of Medicine,

10 Chulalongkorn University, Bangkok, Thailand

12 Corresponding author:

13 Yong Poovorawan, yong.p@chula.ac.th 


\section{ABSTRACT}

15 The core antigen of the hepatitis $\mathrm{C}$ virus (HCV Ag) presents an alternative marker to HCV RNA

16 when screening patients for HCV viremia. This study sought to evaluate the utility of HCV Ag

17 as a marker to assess active HCV infection in individuals residing in an HCV endemic area.

18 From $298 \mathrm{HCV}$-seropositive individuals evaluated for the presence of anti-HCV antibody, HCV

19 Ag and HCV RNA, anti-HCV antibody was detected in 252 individuals (signal-to-cutoff ratios $\geq$

20 5), HCV RNA was detected in 222 individuals (88\%), and HCV Ag was reactive ( $\geq 3$ fmol/L) in

21220 individuals (87\%). HCV genotype 1, 3, and 6 were identified. HCV Ag significantly

22 correlated with HCV RNA irrespective of HCV genotype and/or HBV co-infection (log HCV

$\left.23 \mathrm{RNA}=2.67+0.95[\log \mathrm{HCV} \mathrm{Ag}], \mathrm{R}^{2}=0.890, p<0.001\right)$. To predict $\mathrm{HCV}$ viremia $(\mathrm{HCV} \mathrm{Ag} \geq$

$243 \mathrm{fmol} / \mathrm{L}$ ), the accuracy, sensitivity, specificity, positive predictive value, and negative predictive

25 value were $99 \%, 99 \%, 100 \%, 100 \%$ and $97 \%$, respectively. We concluded that HCV Ag was a

26 good surrogate marker for HCV RNA and could be used to diagnose active HCV infection in a

27 resource-limited setting. As a result, a cost-effective strategy for screening and identifying active

$28 \mathrm{HCV}$ carriers using HCV Ag detection would enable more patients access to efficacious and

29 increasingly affordable direct-acting antivirals (DAAs) for the treatment of HCV infection. 


\section{INTRODUCTION}

Infection with hepatitis $\mathrm{C}$ virus $(\mathrm{HCV})$ can lead to acute or chronic hepatitis, liver fibrosis, cirrhosis, end-stage liver disease, and hepatocellular carcinoma (Perz et al., 2006). Disease progression after HCV infection depends on factors including gender, coinfection with HIV, alcohol consumption, and duration of chronic infection (Hajarizadeh et al., 2013 ; El-Serag, 2012). The global population seroprevalence of anti-HCV antibodies is estimated at around $1.6 \%$, or roughly 115 million people (Gower et al., 2014). The presence of HCV antibodies can be found in spontaneous clearance, resolved infection post-treatment or persistently active disease. Early treatment for HCV infection especially in the acute phase can facilitate viral clearance and prevent chronic infection, thereby limiting $\mathrm{HCV}$-induced liver damage and mortality (Jaeckel et al., 2001; Gerlach et al., 2003; Singal et al., 2010).

Screening for anti-HCV antibody status often facilitates HCV surveillance in the community (Meffre et al., 2010; Garcia Comas et al., 2015; Morisco et al., 2016). Although simple, such assay cannot differentiate between past and present infection and requires supplemental HCV RNA testing to confirm active HCV infection and monitor antiviral treatment. Despite its high sensitivity and reliability, HCV RNA assay involving nucleic acid testing (NAT) and quantitative real-time RT-PCR requires skilled laboratory personnel, sophisticated equipment, and expensive reagents (Roth et al., 2012; Halfon et al., 2006). Therefore routine screening using these tests is limited particularly for many resourceconstrained setting. In contrast, testing for $\mathrm{HCV}$ core antigen ( $\mathrm{HCV} \mathrm{Ag)} \mathrm{presents} \mathrm{a} \mathrm{more}$ attractive alternative owing to the lower cost and short turnaround time. $\mathrm{HCV} \mathrm{Ag} \mathrm{has} \mathrm{been}$ shown to be an indirect marker for HCV replication comparable to the detection of HCV RNA (Schuttler et al., 2004; Bouvier-Alias et al., 2002; Ottiger et al., 2013; Florea et al., 2014). In 
53 addition to serving as a reliable marker to diagnose active $\mathrm{HCV}$ infection, $\mathrm{HCV}$ Ag can also be

54 used to evaluate the treatment response to antiviral therapy (Mederacke et al., 2009; Rockstroh et

55 al., 2017; Alonso et al., 2017). Another advantage of HCV Ag assay is that it can often be

56 performed on the same instrument and simultaneously with the anti-HCV assay, an added value

57 when determining the HCV prevalence in the community (Kuo et al., 2012; Mixson-Hayden et

58 al., 2015).

New and effective therapeutic direct-acting antivirals (DAAs) taken orally have become widely available in recent years. DAAs have advanced HCV therapy with higher rates of

61 sustained-virological response (SVR) post-treatment than those obtained from traditional interferon-based therapies independent of HCV genotype (Sulkowski et al., 2014; Zeuzem et al., 2014; Gane et al., 2015). Despite the availability of these highly efficient drugs, asymptomatic nature of $\mathrm{HCV}$ infection and expensive diagnostic screening process represent major obstacles in identifying and treating HCV-infected individuals (Cox, 2015). Therefore, a simple, costeffective testing feasible for routine HCV screening would be ideal for a developing country

67 such as Thailand. In this study, we aimed to evaluate the diagnostic utility of HCV Ag as an

68 alternative to HCV RNA to identify active HCV infection in a relatively high endemic area. We 69 also assessed the cost feasibility and savings of implementing such program towards public 70 health policy in an era of DAAs. 
71 73

\section{MATERIALS AND METHODS}

This follow-up study examined the prevalence and genotypes of HCV found in Petchabun and Khon Kaen province and comprised part of a previous HCV surveillance project involving 3077 samples from high- and average-level HCV endemic areas (Wasitthankasem et al., 2017). All $\mathrm{HCV}$-seropositive individuals were informed of their status and invited to participate in confirmatory testing for $\mathrm{HCV}$ infection using anti-HCV, HCV Ag, and HCV RNA assays combined with liver enzyme levels and liver stiffness tests in March 2016. The study protocol was approved by the institutional review board of the Faculty of Medicine, Chulalongkorn University (IRB No. 258/58). Objectives of the study were explained to the patients and written informed consents were obtained.

\section{Study subjects}

Of the 310 eligible individuals with positive anti-HCV Ab results, 270 subjects participated in the follow-up study (Fig. 1). Another 28 subjects with anti-HCV positive status established after blood donor screening were also enrolled in this study. In all, 298 subjects (aged 34-64 years) provided demographic information and blood samples. Liver function data including aspartate aminotransferase (AST) and alanine transaminase (ALT) levels were obtained, and HCV viral loads were determined from blood plasma. The degree of liver fibrosis was assessed by transientelectrography (FibroScan, Echosens, Paris, France). Hepatitis B virus (HBV) and HIV status were previously determined using HBsAg and HIV Ag/Ab automated screening (ARCHITECT, Abbott Diagnostics, Wiesbaden, Germany).

\section{Anti-HCV serological test}


92 All sera were tested for an anti-HCV antibody using automated chemiluminescent microparticle immunoassays (CMIA) (ARCHITECT anti-HCV assay, Abbott Diagnostics, Wiesbaden,

94 Germany). Signal-to-cutoff ratio (S/CO) indicated the presence of anti-HCV, with $\mathrm{S} / \mathrm{CO} \geq 1.00$

95 automatically assigned as reactive by the ARCHITECT i1000SR platform. The U.S. Centers for Disease Control and Prevention (CDC) recommended the true predictive result above 95\% when the $\mathrm{S} / \mathrm{CO}$ ratio is $\geq 5$. Therefore, the latter was adopted, and reactive anti-HCV samples were further categorized based on this criterion.

\section{HCV RNA measurement}

Plasma HCV RNA level was determined using an automated in vitro reverse-transcription polymerase chain reaction (RT-PCR) assay (Abbott RealTime HCV assay, Abbott Molecular, IL). The lower and upper limits of quantitation of this kit were 12 and 100,000,000 IU/mL, or $\log 1.08$ and $\log 8.00 \mathrm{IU} / \mathrm{mL}$, with a linearity range between $8.21 \log \mathrm{IU} / \mathrm{mL}$ to $0.91 \log \mathrm{IU} / \mathrm{mL}$ (according to the manufacturer's instructions). Samples over the upper detection limit were examined for viral genotype and were not included in further analyses. Samples with HCV RNA level $<12 \mathrm{IU} / \mathrm{mL}$ and $\geq 12 \mathrm{IU} / \mathrm{mL}$ were defined as negative and positive for HCV RNA, respectively.

\section{HCV Ag measurement}

$\mathrm{HCV}$ core antigen (HCV Ag) quantitation was determined by automated assays using an Architect i2000SR system (ARCHITECT HCV Ag, Abbott Diagnostics, Wiesbaden, Germany). This assay is a CMIA based on the interaction between monoclonal anti-HCV and HCV Ag. A $\mathrm{HCV}$ Ag concentration $<3 \mathrm{fmol} / \mathrm{L}$ was interpreted as nonreactive, and the other samples with higher titers were interpreted as being reactive for $\mathrm{HCV} \mathrm{Ag}$. The detection limit ranged from 0 to 
$11420,000 \mathrm{fmol} / \mathrm{L}$. Therefore, samples with HCV Ag over the limit of detection $(20,000 \mathrm{fmol} / \mathrm{L})$

115 were further diluted (by a factor 1:9), and re-examined by automated dilution protocol in the

116 Architect i2000SR. The machine automatically calculated and reported the final HCV Ag

117 concentration.

\section{HCV genotyping}

119 Genotype was determined based on the nucleotide sequence of the HCV core region. HCV RNA was extracted, and nested RT-PCR of the partial core region was performed on the samples with HCV RNA $\geq 12 \mathrm{IU} / \mathrm{mL}$. Primer pairs of $954 \mathrm{~F} / 410 \mathrm{R}$ were used in the first round, and 953F/951R were used in the second round, as previously described (Wasitthankasem et al., 2015). Target PCR amplicon of the core region was purified (ExpinGel SV, GeneAll Biotechnology, Seoul, 124 Korea) and sequenced.

\section{Data and statistical analysis}

126 Continuous variables such as the level of AST and ALT were described in particular groups with $127<30 \mathrm{U} / \mathrm{mL}$ and $\geq 30 \mathrm{U} / \mathrm{mL}$, whereas liver stiffness was categorized according to the Metavir 128 score in which F0-F2 equals liver stiffness $<9.5 \mathrm{kPa}$ and F3-F4 equals liver stiffness $\geq 9.5 \mathrm{kPa}$ (Castera et al., 2008). The difference between groups and group means was evaluated by Chisquared test and one-way ANOVA using a Bonferroni model, respectively. Association between the level of HCV RNA and HCV Ag was analyzed in log scale by a linear regression model. Differences of regression data among genotypes were analyzed by general linear model and univariate analysis. The regression model evaluated the odds ratios and $95 \%$ confidence intervals 134 of demographic information associated with HCV RNA status. A $p$-value $<0.05$ was considered 135 statistically significant. Sensitivity, specificity, positive predictive value (PPV), negative 
136 predictive value (NPV), and accuracy of the diagnostic tests for anti-HCV and HCV Ag markers

137 were calculated using HCV RNA status as a gold standard. All statistical analyses were

138 performed using SPSS version 11.5for Windows (SPSS, Chicago, IL). 


\section{RESULTS}

\section{Demographic information of participants}

141 The study design is shown in Figure 1. From 298 individuals in this study, 290 were reactive to 142 anti-HCV $(\mathrm{S} / \mathrm{CO} \geq 1.0)$. There were $242(83.4 \%)$ males and $48(16.6 \%)$ females (mean age 50.4

$143 \pm 7.2$ and $48.4 \pm 8.4$ years, respectively). Many of the anti-HCV reactive individuals had 144 elevated levels ( $\geq 30 \mathrm{U} / \mathrm{mL})$ of AST (65.5\%), ALT (51.7\%) and advanced liver fibrosis (47.1\%, 145 Metavir score: F3-F4) (Table 1). Among the anti-HCV reactive individuals, 13 of 266 with 146 available $\mathrm{HBV}$ status were found reactive to $\mathrm{HBsAg}$, while 1 was reactive to $\mathrm{HIV} \mathrm{Ag/Ab.}$ (222/290) and absence (68/290) of HCV RNA (Fig. 1). One sample with HCV RNA exceeding the upper limit of detection (more than $\log 8 \mathrm{IU} / \mathrm{mL}$ ) was considered RNA positive but not included in further analyses. All but two of the HCV RNA-positive subjects were reactive to HCV Ag ( $\geq 3 \mathrm{fmol} / \mathrm{L})$. A majority of samples with positive viral RNA showed elevated liver enzymes $(\mathrm{AST}=77.0 \%$ and $\mathrm{ALT}=62.2 \%)$ and had severe fibrosis $(54.3 \%)($ Table 1$)$. There were significant associations between positive HCV RNA and male gender (OR 2.3, 95\% CI: $1.2,4.5, p=0.013$ ), elevated liver enzyme levels (AST; OR 8.6, 95\% CI: 4.7, 16.0, $p<0.001$ and ALT; OR 7.7, 95\% CI: 3.9, 15.1, $p<0.001)$ and advance liver stiffness (OR 3.9, 95\% CI: $2.1,7.1, p<0.001$ ). Genotyping of $\mathrm{HCV}$ revealed 61 samples with genotype 1 (subtype $1 \mathrm{a}=44$ and $1 b=17), 71$ samples with genotype 3 (subtype $3 a=69$ and $3 b=2$ ) and 90 samples with 158 genotype 6 (subtype $6 c=1,6 f=72,6 i=4$ and $6 n=13$ ). 
160 A schematic diagram of anti-HCV, HCV Ag, and HCV RNA testing in this study is shown in

161 Figure 2. Thirty-eight out of 290 individuals with anti-HCV S/CO $<5.0$ and $\mathrm{HCV} \mathrm{Ag}<3.0$

$162 \mathrm{fmol} / \mathrm{L}$ tested negative for HCV RNA. Of the 252 samples with anti-HCV S/CO $\geq 5,220$

163 samples with $\mathrm{HCV} \mathrm{Ag} \geq 3 \mathrm{fmol} / \mathrm{L}$ were positive for HCV RNA. In 32 samples with anti-HCV

$164 \mathrm{~S} / \mathrm{CO} \geq 5$ and $\mathrm{HCV} \mathrm{Ag}<3 \mathrm{fmol} / \mathrm{L}, 2$ samples were positive for HCV RNA.

165

166

167

168

169

170

171

172

173

174

175

176

177

Among $13 \mathrm{HBV}$ reactive samples, there were $6 \mathrm{HCV}$ RNA positive samples, 5 of which were positive for HCV Ag. One sample showed evidence of triple infection with HIV, HBV, and $\mathrm{HCV}$.

\section{Correlation of anti-HCV and HCV Ag with HCV RNA level}

Examination of the correlations among anti-HCV, HCV Ag, and HCV RNA levels in log scale showed that anti-HCV significantly correlated with HCV RNA $(\log$ HCV RNA $=-0.882+5.492$ [log anti-HCV], $\left.\mathrm{R}^{2}=0.534, p<0.001\right)($ Fig. 3a). Using an anti-HCV S/CO cut-off at 5, there were 30 false-positive (FP) samples with HCV RNA < 12 IU/mL (Table S1) and no falsenegatives (FN). Better correlation was observed between HCV Ag and HCV RNA level (log HCV RNA $=2.67+0.95\left[\log \mathrm{HCV}\right.$ Ag], $\left.\mathrm{R}^{2}=0.890, p<0.001\right)($ Fig. 3b). Taking an HCV Ag cut-off at 3 fmol/L, only two FN with HCV RNA levels of 501 and $1445 \mathrm{IU} / \mathrm{mL}$ were identified (Fig. $3 \mathrm{~b}$ and Table S1). Both samples had HCV Ag levels of 0.0 and $2.1 \mathrm{fmol} / \mathrm{L}$ and were of genotype 3a (Fig. 4b).

The mean levels of HCV RNA in the samples with genotype $1(\log 6.0 \pm 0.9 \mathrm{IU} / \mathrm{mL})$, genotype $3(\log 5.6 \pm 1.1 \mathrm{IU} / \mathrm{mL})$, and genotype $6(\log 6.1 \pm 0.8 \mathrm{IU} / \mathrm{mL})$ were determined along with the mean HCV Ag (genotype 1, $\log 3.5 \pm 1.0 \mathrm{fmol} / \mathrm{L}$; genotype 3, $2.9 \pm 1.1 \mathrm{fmol} / \mathrm{L}$; genotype $6,3.8 \pm 0.7 \mathrm{fmol} / \mathrm{L}$ ) (Table 2). Genotypes showed significant differences in the log mean of both 
182 HCV RNA and HCV Ag ( $p=0.001$ and $p<0.001$, respectively). Samples with HCV genotype 3 183 had lower levels of HCV RNA and HCV Ag than genotype $1(p=0.014$ and $p=0.001$, 184 respectively) and $6(p=0.001$ and $p<0.001$, respectively). Based on the regression data, $\mathrm{HCV}$ 185 Ag showed greatest correlation with HCV RNA in samples with genotype $1(\log$ HCV RNA = 186 $2.97+0.87\left[\log \mathrm{HCV}\right.$ Ag], $\left.\mathrm{R}^{2}=0.905, p<0.001\right)$ followed by genotype $6(\log \mathrm{HCV} \mathrm{RNA}=$ $2.323+1.01\left[\log \mathrm{HCV}\right.$ Ag] $\left., \mathrm{R}^{2}=0.870, p<0.001\right)$, and genotype $3(\log \mathrm{HCV} \mathrm{RNA}=2.75+$ $\left.0.97[\log \mathrm{HCV} \mathrm{Ag}], \mathrm{R}^{2}=0.848, p<0.001\right)$ (Fig. 4 and Table 2). Finally, the slight difference in regression data among genotypes was not statistically significant $(p=0.102)$. HCV mono-infection $(\mathrm{N}=215, \log 5.9 \pm 1.0 \mathrm{IU} / \mathrm{mL}$ and $\log 3.4 \pm 1.0 \mathrm{fmol} / \mathrm{L})$ and $\mathrm{HCV} / \mathrm{HBV}$ co-infection $(\mathrm{N}=5, \log 5.7 \pm 1.7 \mathrm{IU} / \mathrm{mL}$ and $\log 3.0 \pm 1.5 \mathrm{fmol} / \mathrm{L})(p$-value $>0.05) . \mathrm{HCV} \mathrm{Ag}$

highly correlated with HCV RNA in HCV/HBV co-infection $(\log \mathrm{HCV}$ RNA $=2.44+1.08[\log$ $\mathrm{HCV} \mathrm{Ag}], \mathrm{R}^{2}=0.968, p=0.002$ ), while correlation of these two markers between monoinfection (HCV/HBV/HIV) had viral load and $\mathrm{HCV}$ Ag at $\log 6.7 \mathrm{IU} / \mathrm{mL}$ and $\log 4.10 \mathrm{fmol} / \mathrm{L}$, respectively.

\section{Evaluation of anti-HCV and HCV Ag assay in predicting HCV infection}

To identify HCV viremia, an anti-HCV S/CO cut-off at 5 showed 89.7\% accuracy, 100\% sensitivity, and 55.9\% specificity. Positive predictive value (PPV) and negative predictive value (NPV) were $88.1 \%$ and $100 \%$, respectively (Table 3). By applying the HCV Ag assay to predict active $\mathrm{HCV}$ infection, a cut-off of $3 \mathrm{fmol} / \mathrm{L}$ had the greatest accuracy $(99.3 \%)$, with 100\% specificity, 99\% sensitivity, 100\% PPV, and 97\% NPV. Using both anti-HCV and HCV Ag 
204 markers $(\mathrm{S} / \mathrm{CO} \geq 5$ and $\mathrm{HCV} \mathrm{Ag} \geq 3 \mathrm{fmol} / \mathrm{L})$, diagnostic predictions of HCV viremia were 205 similar to those using HCV Ag marker alone (Table S1). 


\section{DISCUSSION}

207 Timely HCV treatment especially during the acute phase of infection has shown promise in

208 multiple HCV genotypes and results in improved prognosis (Jaeckel et al., 2001). Identifying

209 actively infected individuals is therefore important in reducing HCV transmission and disease

210 burden, especially in areas of endemicity. Although, anti-HCV screening is the primary test for

211 diagnosis of HCV infection, supplemental testing is still needed to discriminate between resolved

212 and viremic infection. The results of this study suggest that anti-HCV Ab tests had a fair

213 correlation with HCV RNA and are appropriate for primary screening due to its high sensitivity.

214 Previously, it was suggested that an appropriate cut-off could predict HCV viremia (Kuo et al.,

215 2012). Thus, this study applied a S/CO cut-off at 5.0 for predicting a true antibody-positive result

$216 \geq 95 \%$ recommended by the U.S. CDC (https://www.cdc.gov/hepatitis/hcv/labtesting.htm).

217 Among samples with anti-HCV S/CO $\geq 5$, HCV RNA was positive in 88.1\% (222 of 252), while

218 those with $\mathrm{S} / \mathrm{CO}<5.0$ were all negative. The latter may have resulted from a false-positive anti-

219 HCV result or an individual with resolved disease and/or low antibody titer. Using this cut-off

220 ratio to predict $\mathrm{HCV}$ infection, high diagnostic sensitivity $(0.0 \% \mathrm{FN}$ and $11.9 \% \mathrm{FP})$ was noted.

221 When the cut-off ratio was adjusted to 15.0, better predictive values for HCV infection were

222 obtained with excellent PPV (98.8\%) and specificity (98.5\%), albeit with poor NPV (32.8\%) and

223 sensitivity (38.3\%) (Table S2). Thus, anti-HCV testing with S/CO at 5.0 was appropriate for the

224 first-line screening.

Unlike anti-HCV Ab, HCV Ag showed excellent diagnostic validity and correlation with HCV RNA. At a cutoff of $3 \mathrm{fmol} / \mathrm{L}, \mathrm{HCV}$ Ag was a good predictive marker of HCV viremia with $0(0.0 \%) \mathrm{FP}$ and $2(2.9 \%) \mathrm{FN}$ cases. The validity of HCV Ag testing was better than the anti-HCV marker that had 99.1\% sensitivity, 100\% specificity, 100\% PPV, 97.1\% NPV and 
229

230

231

232

233

234

235

236

237

238

239

240

241

242

243

244

245

246

247

248

249

250

251

99.3\% accuracy. It has been suggested that combining anti-HCV and HCV Ag at the appropriate cutoff point would improve the predictive value for HCV viremia, but the validity was similar to HCV Ag alone when combining those two markers (Kuo et al., 2012). In addition, HCV Ag correlates well with RNA levels and may therefore serve as a predictor for response-guided therapy and for monitoring treatment response (Nguyen et al, 2017; Alonso et al., 2017).

The $2 \mathrm{FN}$ cases from the HCV Ag assay had low viral loads and were of genotype 3. These results may be related to the viral level and detection limit of the respective genotypes. Low levels of HCV RNA tended to increase the coefficient of variation and contributed to FN on HCV Ag assays (Aghemo et al., 2016; Ottiger et al., 2013). Several studies suggest that the lower limit of HCV Ag detection is equivalent to HCV RNA between 1000 and $5000 \mathrm{IU} / \mathrm{mL}$, therefore low RNA level in these 2 samples $(501 \mathrm{IU} / \mathrm{mL}$ and $1445 \mathrm{IU} / \mathrm{mL})$ may have contributed to the FN result (Florea et al., 2014; Freiman et al., 2016; Ottiger et al., 2013). In addition, adequate analytical sensitivity at $3 \mathrm{fmol} / \mathrm{L}$ of $\mathrm{HCV} \mathrm{Ag}$ of genotype 3 required approximately $1002 \mathrm{IU} / \mathrm{mL}$ of HCV RNA, which was higher than for genotype 1 (896 IU/mL) (Ross et al., 2010; Tillmann, 2014). Similar to this cohort, greater variation in genotype 3 samples with low HCV Ag but high HCV RNA was previously reported (Ottiger et al., 2013; Mederacke et al., 2009). Discordant result found in this study $(0.7 \%, 2 / 290)$ could potentially be resolved with a confirmatory RNA testing (e.g. reactive anti-HCV and non-reactive HCV Ag) (Rockstroh et al., 2017).

A meta-analysis demonstrated that $\mathrm{HCV}$ Ag had excellent correlation with viremia despite limitations on the effect of HCV genotypes and HBV or HIV co-infection (Freiman et al., 2016). A significant difference was observed in the log mean of viral RNA and antigen levels among genotypes, but this was not apparent in the correlation between these two markers. 
252 Previous studies also reported that HCV Ag of genotype 1, 2, 3 and 4 had good correlation with

253 viral load (Mederacke et al., 2009; Ottiger et al. 2013; Ross et al., 2010). Our study also showed

254 good correlation between HCV Ag and RNA in HCV/HBV co-infection samples. However, poor

255 correlation in the HBV co-infection group may sometimes occur especially with genotypes other

256 than genotype 1 (Mederacke et al., 2012). This may be attributed to very low or very high

257 concentration of HCV Ag relative to HCV RNA in some samples. Therefore, HCV Ag retesting

258 should be performed in the samples with very low or very high concentrations. Excellent

259 correlation had been reported in HCV/HIV co-infection (Mederacke et al., 2012; Thong et al.,

260 2015), but that information was insufficient in triple infection samples. We found only one

261 sample with HCV/HBV/HIV triple infection and elevated HCV viremia and HCV Ag. Further

262 studies are required to elucidate the correlations in subjects with dual infections and triple

263 infections.

Previous studies examining $\mathrm{HCV}$ Ag in $\mathrm{HCV}$ infection were conducted in industrialized

countries (Mederacke et al., 2009; Mixson-Hayden et al., 2015; Rockstroh et al., 2017; Freiman

et al., 2016), while data from low- to middle-income countries (LMIC) have been scarced (Khan

et al., 2017; Freiman et al., 2016). Our finding provided the evidence of the utility of HCV Ag

for HCV screening in LMIC endemic for HCV due to the assay's high diagnostic validity and

lower cost than an RNA assay, which potentially could improve access to treatment and care in

LMIC (Wang et al., 2017; Khan et al., 2017).

272 increasing the proportion of diagnosed persons by up to $90 \%$ by the year 2030 (WHO, 2017).

273 This policy will require a substantial investment. Fortunately, affordable and highly efficacious 
275 eradicating $\mathrm{HCV}$, results from our study and others suggest an alternative screening and

276 diagnostic strategy to treat HCV infection, especially in the era of DAAs (Fig. 5). When

277 screening initially involves anti-HCV antibody and confirmatory HCV Ag assay, followed by

278 HCV RNA testing on HCV Ag-negative samples, a cost-effective algorithm by us demonstrate a

279 considerable reduction, roughly $48 \%$ compared to the standard expenditure (standard algorithm;

280 anti-HCV test followed by RNA assay, File S1) and is consistent with that proposed by others

281 (Jülicher et al, 2017). This strategy would effectively provide equal diagnostic performance that

282 supports the possibility of large-scale implementation.

283 In conclusion, our population-based study showed high validity of HCV Ag as a reliable

284 marker for diagnosis of active HCV infection. This marker showed excellent correlation with the

285 viral RNA irrespective of genotypes and HBV co-infection. In addition, HCV Ag can serve as a

286 supplemental marker after anti-HCV testing to reduce the sample number requiring further

287 confirmatory RNA assays. A proposed cost-effective strategy would reduce the financial burden

288 required for national screening and improve access to HCV treatment and care in the era of

289 affordable DAAs. 


\section{ACKNOWLEDGMENTS}

291 We would like to thank Ms Supapith Saiyatha and Mr. Chaiwat Thongmai, Phetchabun

292 Provincial Public Health Office, Ms. Napha Thanetkongtong and Dr. Viboonsak Vuthitanachot, 293 Chumpare Hospital, Chum Phae, Khon Kaen and Ms Saowakon Sochoo, Lomkao Crown Prince

294 Hospital for specimen collection and collaboration.

295

296

297

298

299

300

301

302

303

304

305

306

307 
308

309

310

311

312

313

314

315

316

317

318

319

320

321

322

323

324

325

326

327

328

329

\section{REFERENCES}

Aghemo A, Degasperi E, De Nicola S, Bono P, Orlandi A, D'Ambrosio R, Soffredini R, Perbellini R, Lunghi G, and Colombo M. 2016. Quantification of Core Antigen Monitors Efficacy of Direct-acting Antiviral Agents in Patients With Chronic Hepatitis C Virus Infection. Clin Gastroenterol Hepatol 14:1331-1336 DOI 10.1016/j.cgh.2016.03.035.

Alonso R, Perez-Garcia F, Ampuero D, Reigadas E, and Bouza E. 2017. New direct-acting antivirals for patients with chronic $\mathrm{HCV}$ infection: can we monitor treatment using an HCV core antigen assay? Diagn Microbiol Infect Dis 87:243-246 DOI 10.1016/j.diagmicrobio.2016.11.010.

Bouvier-Alias M, Patel K, Dahari H, Beaucourt S, Larderie P, Blatt L, Hezode C, Picchio G, Dhumeaux D, Neumann AU, McHutchison JG, and Pawlotsky JM. 2002. Clinical utility of total HCV core antigen quantification: a new indirect marker of HCV replication. Hepatology 36:211-218 DOI 10.1053/jhep.2002.34130.

Castera L, Forns X, and Alberti A. 2008. Non-invasive evaluation of liver fibrosis using transient elastography. J Hepatol 48:835-847 DOI 10.1016/j.jhep.2008.02.008.

Cox AL. 2015. MEDICINE. Global control of hepatitis C virus. Science 349:790-791 DOI 10.1126/science.aad1302.

El-Serag HB. 2012. Epidemiology of viral hepatitis and hepatocellular carcinoma. Gastroenterology 142:1264-1273 e1261 DOI 10.1053/j.gastro.2011.12.061.

Florea D, Neaga E, Nicolae I, Maxim D, Popa M, and Otelea D. 2014. Clinical usefulness of $\mathrm{HCV}$ core antigen assay for the management of patients with chronic hepatitis C. $J$ Gastrointestin Liver Dis 23:393-396 DOI 10.15403/jgld.2014.1121.234.chcv. 
330 Freiman JM, Tran TM, Schumacher SG, White LF, Ongarello S, Cohn J, Easterbrook PJ, Linas

331 BP, and Denkinger CM. 2016. Hepatitis C Core Antigen Testing for Diagnosis of

332

333

334

335

336

337

338

339

340

341

342

343

344

345

346

347

348

349

350

351

352 Hepatitis C Virus Infection: A Systematic Review and Meta-analysis. Ann Intern Med 165:345-355 DOI 10.7326/M16-0065.

Gane EJ, Hyland RH, An D, Svarovskaia E, Pang PS, Brainard D, and Stedman CA. 2015. Efficacy of ledipasvir and sofosbuvir, with or without ribavirin, for 12 weeks in patients with HCV genotype 3 or 6 infection. Gastroenterology 149:1454-1461 e1451 DOI 10.1053/j.gastro.2015.07.063.

Garcia Comas L, Ordobas Gavin M, Sanz Moreno JC, Ramos Blazquez B, Gutierrez Rodriguez A, Astray Mochales J, and Moreno Guillen S. 2015. Prevalence of hepatitis C antibodies in the population aged 16-80 years in the Community of Madrid 2008-2009. J Med Virol 87:1697-1701 DOI 10.1002/jmv.24219.

Gerlach JT, Diepolder HM, Zachoval R, Gruener NH, Jung MC, Ulsenheimer A, Schraut WW, Schirren CA, Waechtler M, Backmund M, and Pape GR. 2003. Acute hepatitis C: high rate of both spontaneous and treatment-induced viral clearance. Gastroenterology 125:80-88 DOI 10.1016/S0016-5085(03)00668-1.

Gower E, Estes C, Blach S, Razavi-Shearer K, and Razavi H. 2014. Global epidemiology and genotype distribution of the hepatitis C virus infection. J Hepatol 61:S45-S57 DOI 10.1016/j.jhep.2014.07.027.

Hajarizadeh B, Grebely J, and Dore GJ. 2013. Epidemiology and natural history of HCV infection. Nat Rev Gastroenterol Hepatol 10:553-562 DOI 10.1038/nrgastro.2013.107.

Halfon P, Bourliere M, Penaranda G, Khiri H, and Ouzan D. 2006. Real-time PCR assays for hepatitis $\mathrm{C}$ virus (HCV) RNA quantitation are adequate for clinical management of 
patients with chronic HCV infection. J Clin Microbiol 44:2507-2511 DOI 10.1128/JCM.00163-06.

355

Jaeckel E, Cornberg M, Wedemeyer H, Santantonio T, Mayer J, Zankel M, Pastore G, Dietrich M, Trautwein C, and Manns MP. 2001. Treatment of acute hepatitis C with interferon alfa-2b. N Engl J Med 345:1452-1457 DOI 10.1056/NEJMoa011232.

Jülicher P, Galli C. 2017. Identifying cost-effective screening algorithms for active hepatitis C virus infections in a high prevalence setting. J Med Econ 1-10 DOI 10.1080/13696998.2017.1369983.

Khan H, Hill A, Main J, Brown A, Cooke G. 2017. Can hepatitis C virus antigen testing replace ribonucleic acid polymearse chain reaction analysis for detecting hepatitis $\mathrm{C}$ virus? a systematic review. Open Forum Infect Dis 4:ofw252 DOI 10.1093/ofid/ofw252

Kuo YH, Chang KC, Wang JH, Tsai PS, Hung SF, Hung CH, Chen CH, and Lu SN. 2012. Is hepatitis $\mathrm{C}$ virus core antigen an adequate marker for community screening? J Clin Microbiol 50:1989-1993 DOI 10.1128/JCM.05175-11.

Mederacke I, Potthoff A, Meyer-Olson D, Meier M, Raupach R, Manns MP, Wedemeyer H, and Tillmann HL. 2012. HCV core antigen testing in HIV- and HBV-coinfected patients, and in HCV-infected patients on hemodialysis. J Clin Virol 53:110-115 DOI 10.1016/j.jcv.2011.11.009.

Mederacke I, Wedemeyer H, Ciesek S, Steinmann E, Raupach R, Wursthorn K, Manns MP, and Tillmann HL. 2009. Performance and clinical utility of a novel fully automated quantitative HCV-core antigen assay. J Clin Virol 46:210-215 DOI 10.1016/j.jcv.2009.08.014. 
375 Meffre C, Le Strat Y, Delarocque-Astagneau E, Dubois F, Antona D, Lemasson JM, Warszawski

376 J, Steinmetz J, Coste D, Meyer JF, Leiser S, Giordanella JP, Gueguen R, and Desenclos

377

378

379

380

381

382

383

384

385

386

387

388

389

390

391

392

393

394

395

396

397

JC. 2010. Prevalence of hepatitis B and hepatitis C virus infections in France in 2004:

social factors are important predictors after adjusting for known risk factors. $J$ Med Virol 82:546-555 DOI 10.1002/jmv.21734.

Mixson-Hayden T, Dawson GJ, Teshale E, Le T, Cheng K, Drobeniuc J, Ward J, and Kamili S. 2015. Performance of ARCHITECT HCV core antigen test with specimens from US plasma donors and injecting drug users. J Clin Virol 66:15-18 DOI 10.1016/j.jcv.2015.02.015.

Morisco F, Loperto I, Stroffolini T, Lombardo FL, Cossiga V, Guarino M, De Feo A, and Caporaso N. 2016. Prevalence and risk factors of HCV infection in a metropolitan area in southern Italy: Tail of a cohort infected in past decades. J Med Virol 89:291-297 DOI 10.1002/jmv.24635.

Nebehay S. 2017. Hepatitis drugs more affordable but disease still deadly: WHO. Available at http://www.reuters.com/article/us-health-hepatitis-who-idUSKBN1AC2GG (accessed 8 August 2017).

Nguyen LT1, Gray E, O'Leary A, Carr M, De Gascun CF; Irish Hepatitis C Outcomes Research Network. 2017. The role of hepatitis C virus core antigen testing in the era of direct acting antiviral therapies: what we can learn from the protease inhibitors. Plos One 11:e0163900 DOI 10.1371/journal.pone.0163900.

Ottiger C, Gygli N, and Huber AR. 2013. Detection limit of architect hepatitis C core antigen assay in correlation with HCV RNA, and renewed confirmation algorithm for reactive anti-HCV samples. J Clin Virol 58:535-540 DOI 10.1016/j.jcv.2013.08.028. 
398 Perz JF, Armstrong GL, Farrington LA, Hutin YJ, and Bell BP. 2006. The contributions of 399 hepatitis B virus and hepatitis $\mathrm{C}$ virus infections to cirrhosis and primary liver cancer 400 worldwide. J Hepatol 45:529-538 DOI 10.1016/j.jhep.2006.05.013.

401

402

403

404

405

406

407

408

409

410

411

412

413

414

415

416

417

418

419

Rockstroh JK, Feld JJ, Chevaliez S, Cheng K, Wedemeyer H, Sarrazin C, Maasoumy B, Herman C, Hackett J, Jr., Cohen DE, Dawson GJ, Cloherty G, and Pawlotsky JM. 2017. HCV core antigen as an alternate test to HCV RNA for assessment of virologic responses to all-oral, interferon-free treatment in HCV genotype 1 infected patients. $J$ Virol Methods 245:14-18 DOI 10.1016/j.jviromet.2017.03.002.

Ross RS, Viazov S, Salloum S, Hilgard P, Gerken G, and Roggendorf M. 2010. Analytical performance characteristics and clinical utility of a novel assay for total hepatitis $\mathrm{C}$ virus core antigen quantification. J Clin Microbiol 48:1161-1168 DOI 10.1128/JCM.01640-09.

Roth WK, Busch MP, Schuller A, Ismay S, Cheng A, Seed CR, Jungbauer C, Minsk PM, Sondag-Thull D, Wendel S, Levi JE, Fearon M, Delage G, Xie Y, Jukic I, Turek P, Ullum H, Tefanova V, Tilk M, Reimal R, Castren J, Naukkarinen M, Assal A, Jork C, Hourfar MK, Michel P, Offergeld R, Pichl L, Schmidt M, Schottstedt V, Seifried E, Wagner F, Weber-Schehl M, Politis C, Lin CK, Tsoi WC, O'Riordan J, Gottreich A, Shinar E, Yahalom V, Velati C, Satake M, Sanad N, Sisene I, Bon AH, Koppelmann M, Flanagan P, Flesland O, Brojer E, Letowska M, Nascimento F, Zhiburt E, Chua SS, Teo D, Stezinar SL, Vermeulen M, Reddy R, Park Q, Castro E, Eiras A, Gonzales Fraile I, Torres P, Ekermo B, Niederhauser C, Chen H, Oota S, Brant LJ, Eglin R, Jarvis L, Mohabir L, Brodsky J, Foster G, Jennings C, Notari E, Stramer S, Kessler D, Hillyer C, Kamel H, Katz L, Taylor C, Panzer S, and Reesink HW. 2012. International survey on 
NAT testing of blood donations: expanding implementation and yield from 1999 to 2009 . Vox Sang 102:82-90 DOI 10.1111/j.1423-0410.2011.01506.x.

422

423

424

425

426

427

428

429

430

431

432

433

434

435

436

437

438

439

440

441

Schuttler CG, Thomas C, Discher T, Friese G, Lohmeyer J, Schuster R, Schaefer S, and Gerlich WH. 2004. Variable ratio of hepatitis C virus RNA to viral core antigen in patient sera. $J$ Clin Microbiol 42:1977-1981 DOI 10.1128/JCM.42.5.1977-1981.

Singal AG, Volk ML, Jensen D, Di Bisceglie AM, and Schoenfeld PS. 2010. A sustained viral response is associated with reduced liver-related morbidity and mortality in patients with hepatitis C virus. Clin Gastroenterol Hepatol 8:280-288 DOI 10.1016/j.cgh.2009.11.018.

Sulkowski MS, Gardiner DF, Rodriguez-Torres M, Reddy KR, Hassanein T, Jacobson I, Lawitz E, Lok AS, Hinestrosa F, Thuluvath PJ, Schwartz H, Nelson DR, Everson GT, Eley T, Wind-Rotolo M, Huang SP, Gao M, Hernandez D, McPhee F, Sherman D, Hindes R, Symonds W, Pasquinelli C, Grasela DM, and Group AIS. 2014. Daclatasvir plus sofosbuvir for previously treated or untreated chronic HCV infection. $N$ Engl J Med 370:211-221 DOI 10.1056/NEJMoa1306218.

Thong VD, Akkarathamrongsin S, Avihingsanon A, Theamboonlers A, Poovorawan Y, and Tangkijvanich P. 2015. The correlation between hepatitis C core antigen and hepatitis C virus RNA levels with respect to human immunodeficiency virus status, hepatitis $\mathrm{C}$ virus genotype and interferon-lambda-4 polymorphism. Intervirology 58:73-79 DOI 10.1159/000370070.

Tillmann HL. 2014. Hepatitis C virus core antigen testing: role in diagnosis, disease monitoring and treatment. World J Gastroenterol 20:6701-6706 DOI 10.3748/wjg.v20.i22.6701.

Wang L, Lv H, Zhang G. 2017. Hepatitis C virus core antigen assay: an alternative 
444 Wasithankasem R, Vichaiwattana P, Siripon N, Posuwan N, Auphimai C, Klinfueng S, Thaneskongtong N, Vuthitanachot V, Saiyatha S, Thongmai C, Suwanpatoomlerd S, 


\section{Table $\mathbf{1}$ (on next page)}

Table 1

Demographic data of individuals with anti-HCV positive serology in the cohort. Samples were categorized according to HCV RNA status. 
1 TABLE 1. Demographic data of individuals with anti-HCV positive serology in the cohort.

2 Samples were categorized according to HCV RNA status.

\begin{tabular}{|c|c|c|c|c|c|}
\hline & $\begin{array}{c}\text { HCV RNA -ve } \\
(N=68)\end{array}$ & $\begin{array}{c}\text { HCV RNA +ve } \\
(\mathrm{N}=222)\end{array}$ & Total $(N=290)$ & $\begin{array}{c}\text { Odds ratio }(95 \% \\
\text { CI) }\end{array}$ & $P$-value \\
\hline Sex (M:F) & $50: 18$ & 192:30 & $242: 48$ & $2.3(1.2,4.5)$ & 0.013 \\
\hline Age (Mean \pm SD) & $50.4 \pm 7.7$ & $50.0 \pm 7.3$ & $50.1 \pm 7.4$ & $0.9(0.6,1.3)$ & 0.687 \\
\hline $\operatorname{AST}(\%)$ & & & & $8.6(4.7,16.0)$ & $<0.001$ \\
\hline$<30 \mathrm{U} / \mathrm{mL}$ & $49(72.1 \%)$ & $51(23.0 \%)$ & $100(34.5 \%)$ & & \\
\hline$\geq 30 \mathrm{U} / \mathrm{mL}$ & $19(27.9 \%)$ & $171(77.0 \%)$ & $190(65.5 \%)$ & & \\
\hline ALT & & & & $7.7(3.9,15.1)$ & $<0.001$ \\
\hline$<30 \mathrm{U} / \mathrm{mL}$ & $56(82.4 \%)$ & $84(37.8 \%)$ & $140(48.3 \%)$ & & \\
\hline$\geq 30 \mathrm{U} / \mathrm{mL}$ & $12(17.6 \%)$ & $138(62.2 \%)$ & $150(51.7 \%)$ & & \\
\hline Liver stiffness $^{\mathrm{a}}(\%)$ & & & & $3.9(2.1,7.1)$ & $<0.001$ \\
\hline F0-F2 & $52(76.5 \%)$ & $101(45.9 \%)$ & $153(52.9 \%)$ & & \\
\hline F3-F4 & $16(23.5 \%)$ & $120(54.3 \%)^{\mathrm{a}}$ & $136(47.1 \%)$ & & \\
\hline
\end{tabular}

3

4 aLiver stiffness (F0-F2, $<9.5 \mathrm{kPa} ; \mathrm{F} 3-\mathrm{F} 4, \geq 9.5 \mathrm{kPa}$ ) could not be determined in 1 individual.

5

6

7

8 


\section{Table 2 (on next page)}

Table 2

Correlation regression between HCV RNA and HCV Ag among different HCV genotypes (in log scale). 
1 TABLE 2. Correlation regression between HCV RNA and HCV Ag among different HCV

2 genotypes (in log scale).

3

\begin{tabular}{|c|c|c|c|c|c|}
\hline & $\begin{array}{c}\text { Genotype } 1 \\
(N=61)\end{array}$ & $\begin{array}{c}\text { Genotype } 3 \\
(N=69)\end{array}$ & $\begin{array}{c}\text { Genotype } 6 \\
(N=90)\end{array}$ & $\begin{array}{c}\text { TOTAL } \\
(\mathbf{N}=\mathbf{2 2 0})^{\mathrm{a}}\end{array}$ & $P$-value \\
\hline $\begin{array}{l}\text { HCV RNA logb } \\
\text { IU/mL (Median) }\end{array}$ & $\begin{array}{l}6.0 \pm 0.9 \\
(6.32)\end{array}$ & $\begin{array}{l}5.6 \pm 1.1 \\
(5.89)\end{array}$ & $\begin{array}{c}6.1 \pm 0.8 \\
(6.43)\end{array}$ & $\begin{array}{l}5.9 \pm 1.0 \\
(5.87)\end{array}$ & 0.001 \\
\hline $\begin{array}{c}\text { HCV Ag } \log ^{b} \\
\text { fmol/L (Median) }\end{array}$ & $\begin{array}{l}3.5 \pm 1.0 \\
(3.79)\end{array}$ & $\begin{array}{l}2.9 \pm 1.1 \\
(3.35)\end{array}$ & $\begin{array}{c}3.8 \pm 0.7 \\
(4.04)\end{array}$ & $\begin{array}{l}3.4 \pm 1.0 \\
\quad(3.7)\end{array}$ & $<0.001$ \\
\hline Regression data $^{c}$ & & & & & 0.102 \\
\hline $\mathbf{R}$ & 0.952 & 0.921 & 0.933 & 0.927 & \\
\hline R-square & 0.905 & 0.848 & 0.870 & 0.860 & \\
\hline p-value & $<0.001$ & $<0.001$ & $<0.001$ & $<0.001$ & \\
\hline
\end{tabular}

4

5 a Of 222 detectable HCV RNA samples, one sample with over limit of detection and one sample

6 with undetectable HCV Ag were excluded.

7 bHCV RNA and HCV Ag level presented as mean \pm SD.

$8 \quad{ }^{\mathrm{c}}$ Correlation between HCV Ag and HCV RNA in log scale. 


\section{Table 3(on next page)}

Table 3

Diagnostic test evaluation of anti-HCV, HCV Ag and combination of anti-HCV and HCV Ag tests to predict HCV active infection in community screening. 
1 TABLE 3. Diagnostic test evaluation of anti-HCV, HCV Ag and combination of anti-HCV and

$2 \mathrm{HCV}$ Ag tests to predict HCV active infection in community screening.

\begin{tabular}{|c|c|c|c|c|c|}
\hline & $\begin{array}{c}\text { \% Sensitivity } \\
\text { (95\% CI) }\end{array}$ & $\begin{array}{c}\text { \% Specificity } \\
\text { (95\% CI) }\end{array}$ & $\begin{array}{c}\text { \% Positive } \\
\text { predictive value } \\
(95 \% \mathrm{CI})\end{array}$ & $\begin{array}{c}\text { \% Negative } \\
\text { predictive value } \\
(95 \% \mathrm{CI})\end{array}$ & $\begin{array}{l}\text { \% Accuracy } \\
\text { (95\% CI) }\end{array}$ \\
\hline Anti-HCV $(\mathrm{S} / \mathrm{CO}=\mathbf{5 . 0})$ & $100.0(98.4-100.0)$ & $55.9(43.3-67.9)$ & $88.1(83.4-91.8)$ & $100.0(90.7-100.0)$ & $89.7(85.6-92.9)$ \\
\hline HCV Ag (3 fmol/L) & $99.1(96.8-99.9)$ & $100.0(94.7-100.0)$ & $100.0(98.3-100.0)$ & $97.1(90.1-99.7)$ & $99.3(97.5-99.9)$ \\
\hline $\begin{array}{c}\text { Anti-HCV }(\mathrm{S} / \mathrm{CO}=5) \\
\text { plus HCV Ag }(3 \mathrm{fmol} / \mathrm{L})^{\mathrm{a}}\end{array}$ & $99.1(96.8-99.9)$ & $100.0(94.7-100.0)$ & $100.0(98.3-100.0)$ & $97.1(90.1-99.7)$ & $99.3(97.5-99.9)$ \\
\hline
\end{tabular}

$4 \quad{ }^{a}$ Anti-HCV (S/CO $\left.\geq 5\right)$ plus HCV Ag $(\geq 3 \mathrm{fmol} / \mathrm{L})$ and others. 


\section{Figure 1}

Figure 1

Evaluation of 298 anti-HCV reactive samples in this study. Anti-HCV reactive samples were collected from individuals who returned to the HCV follow-up study for the treatment program (270 from the previous HCV study and 28 from self anti-HCV screening) (26). AntiHCV nonreactive samples were excluded, and reactive samples were tested for liver function enzymes, liver stiffness, HCV RNA level and HCV Ag level. Viral genotypes were examined in samples with HCV RNA $\geq 12 \mathrm{IU} / \mathrm{mL}$. AST, aspartase aminotransferase; ALT, alanine transaminase. 


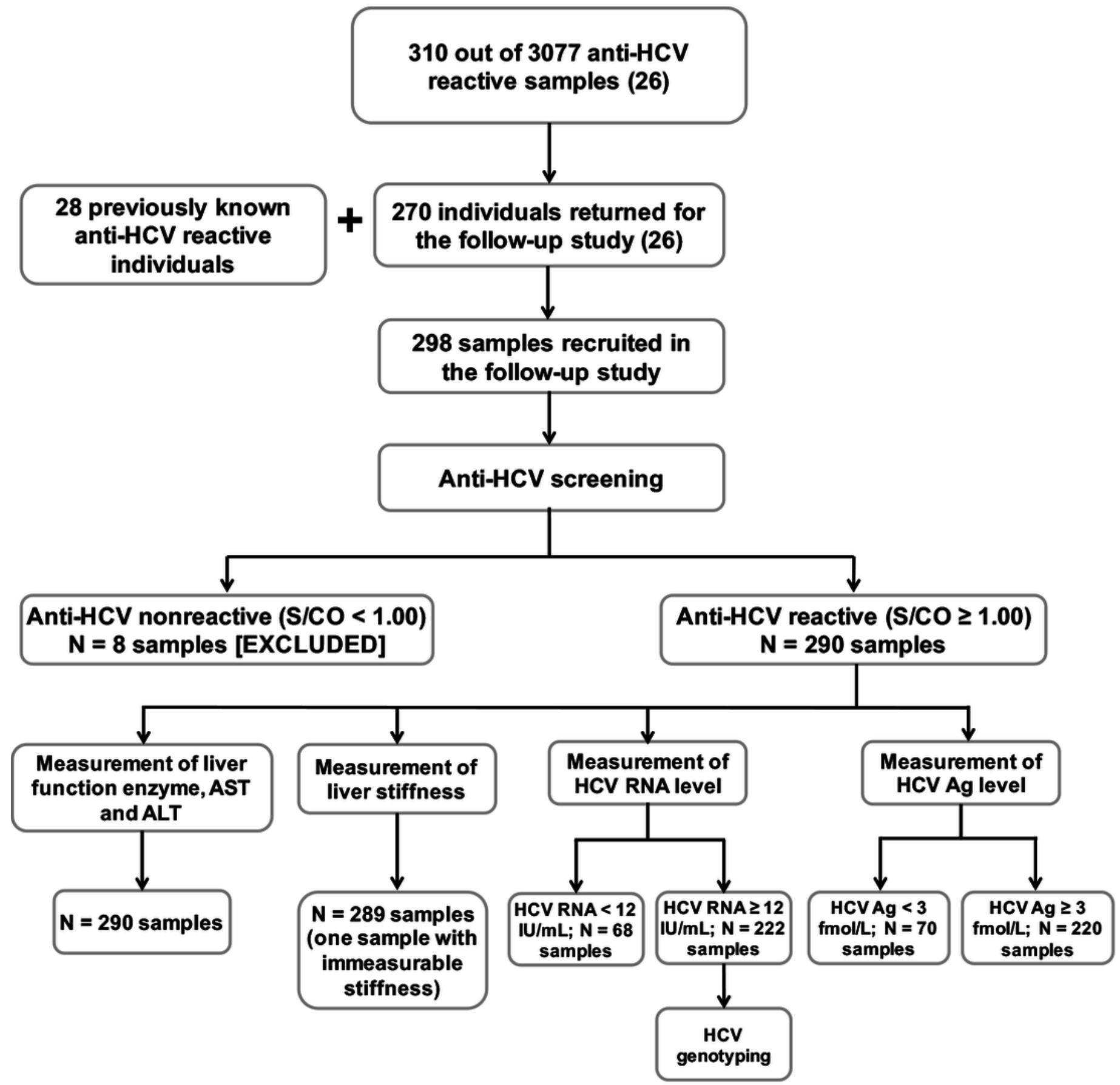


Figure 2

Figure 2

Schematic diagram of all 290 anti-HCV reactive samples. Anti-HCV reactive samples were categorized based on $\mathrm{S} / \mathrm{CO}$ ratio $=5 . \mathrm{HCV}$ Ag level was determined in all anti-HCV reactive samples and sample with HCV Ag $\geq 3$ fmole/L was designated as reactive. HCV RNA level was determined to confirm HCV active infection with the presence of RNA level $\geq 12 \mathrm{IU} / \mathrm{mL}$.

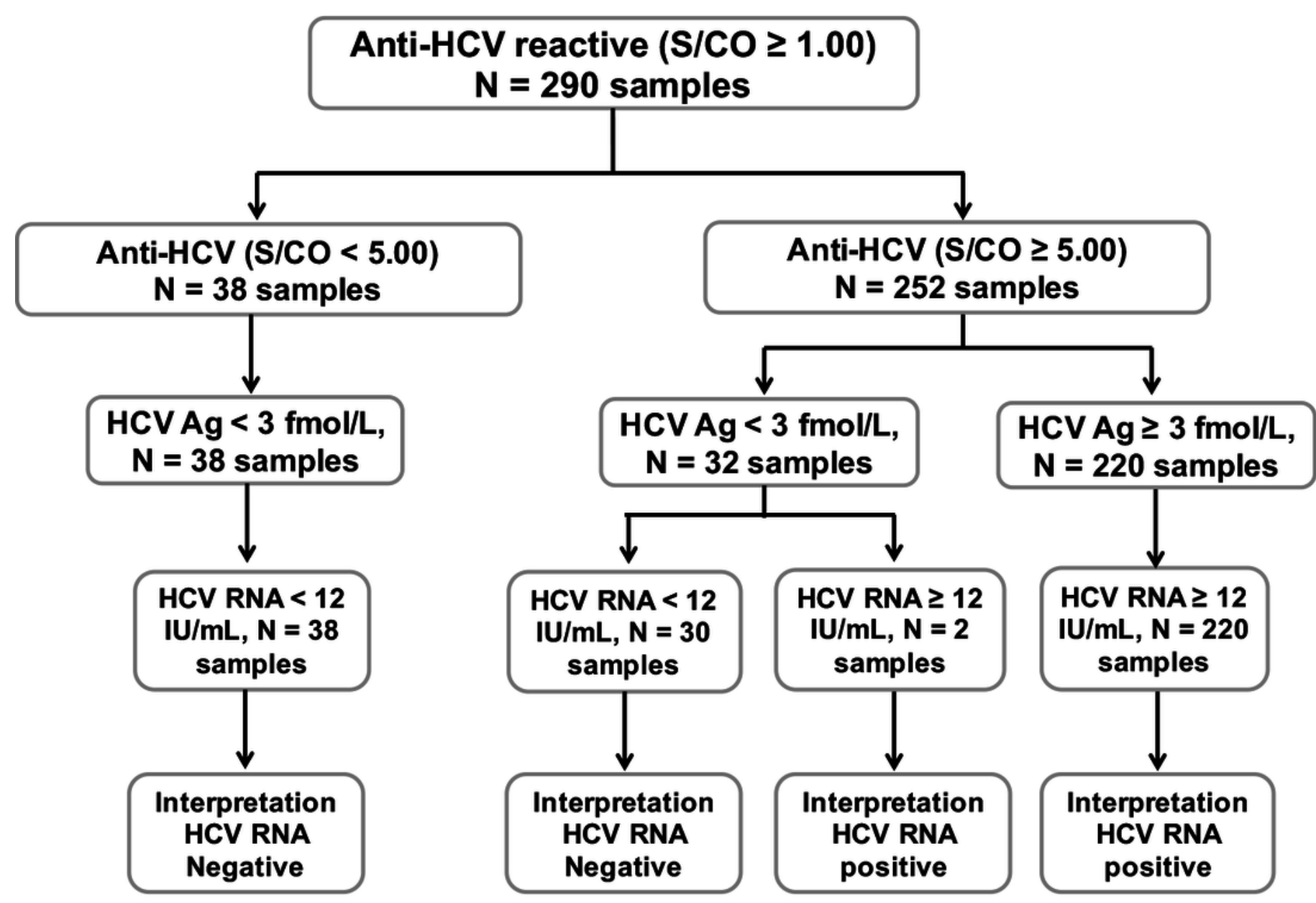




\section{Figure 3}

Figure 3

Correlation of anti-HCV and HCV Ag with HCV RNA level. Anti-HCV and HCV RNA level were analyzed in log scale (a). The lower limit of detection line for HCV RNA was $12 \mathrm{IU} / \mathrm{mL}$. The cutoff line of anti-HCV was 5.0 S/CO. HCV Ag and HCV RNA concentration were analyzed in log scale (b). The lower limit of detection line for HCV RNA was $12 \mathrm{lU} / \mathrm{mL}$. The cutoff line of HCV Ag was $3 \mathrm{fmol} / \mathrm{L}$. 


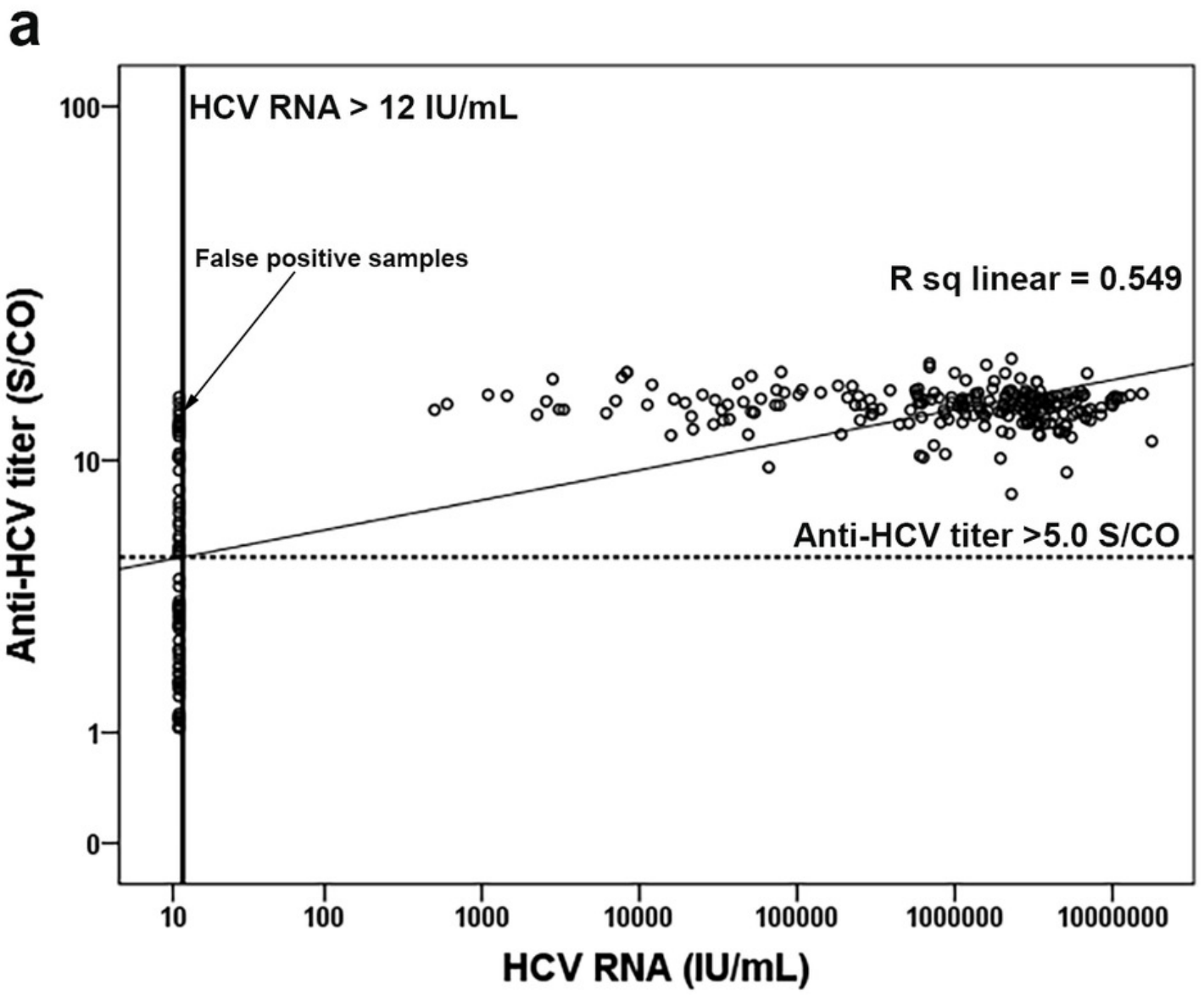

b

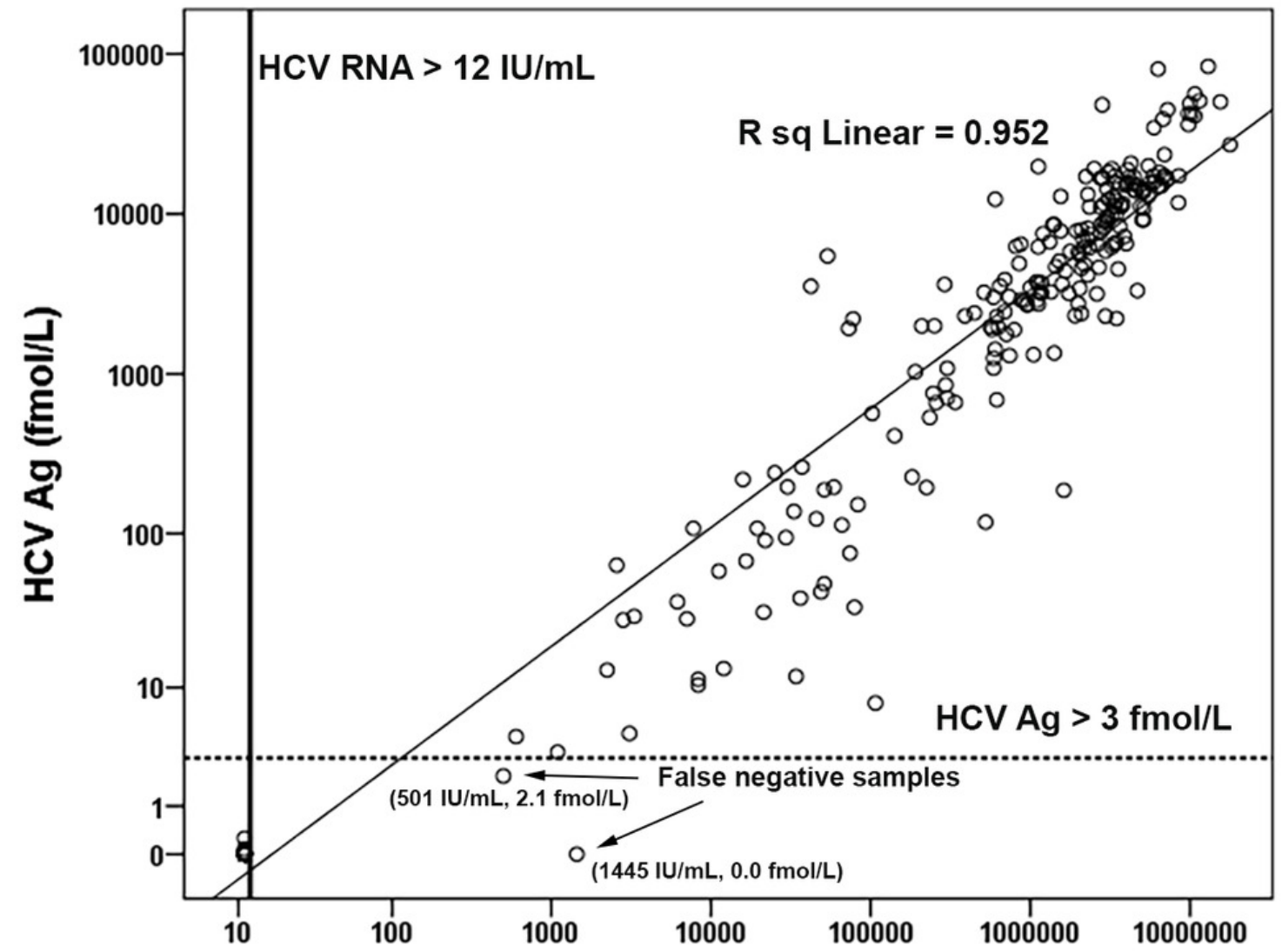




\section{Figure 4}

Figure 4

Correlation of HCV Ag with HCV RNA concentration for different genotypes. Comparison of HCV Ag and HCV RNA level was analyzed in log scale for genotype 1 (a), genotype 3 (b) and genotype 6 (c). The lower limit of detection line for HCV RNA was $12 \mathrm{IU} / \mathrm{mL}$. The cutoff line of HCV Ag was $3 \mathrm{fmol} / \mathrm{L}$. 


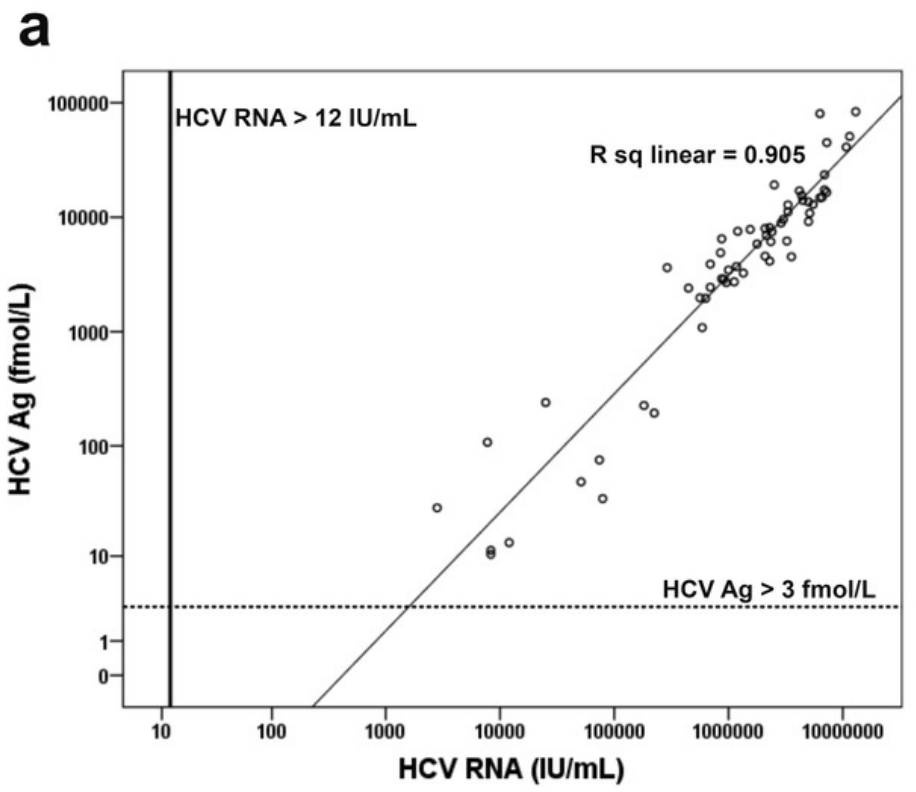

b

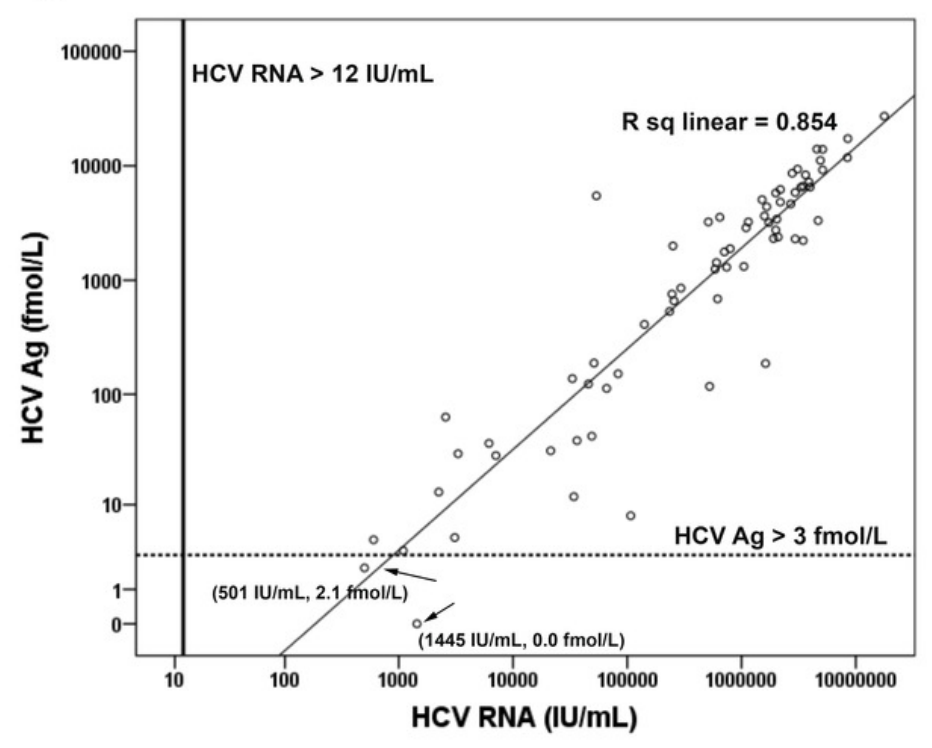

C

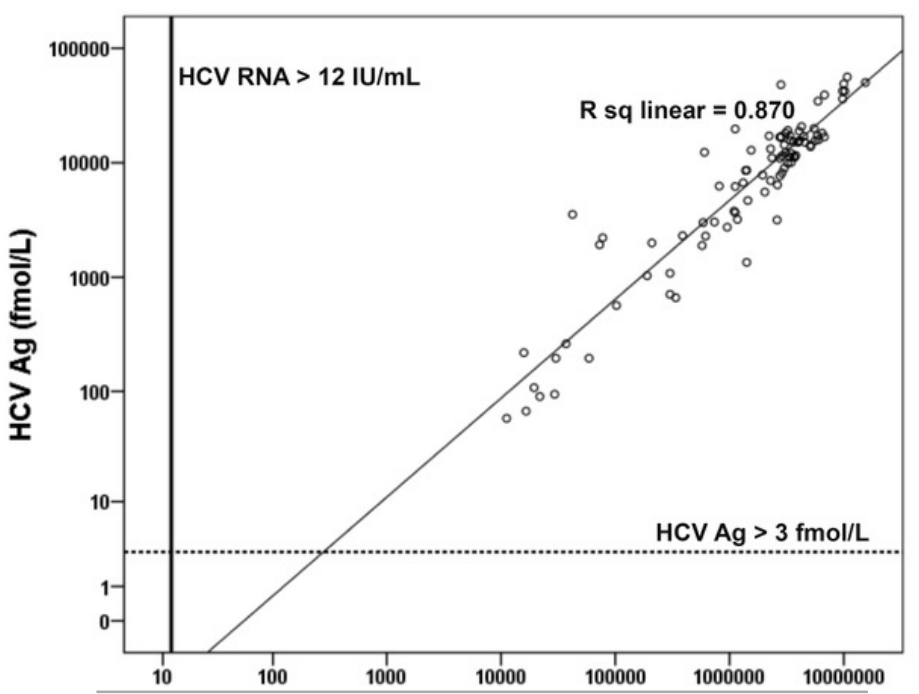

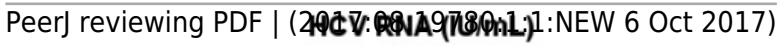


Figure 5

Figure 5

Optional screening strategy for treatment of HCV infection. HCV genotyping is an option depends on IFN- or DAAs-based therapy.

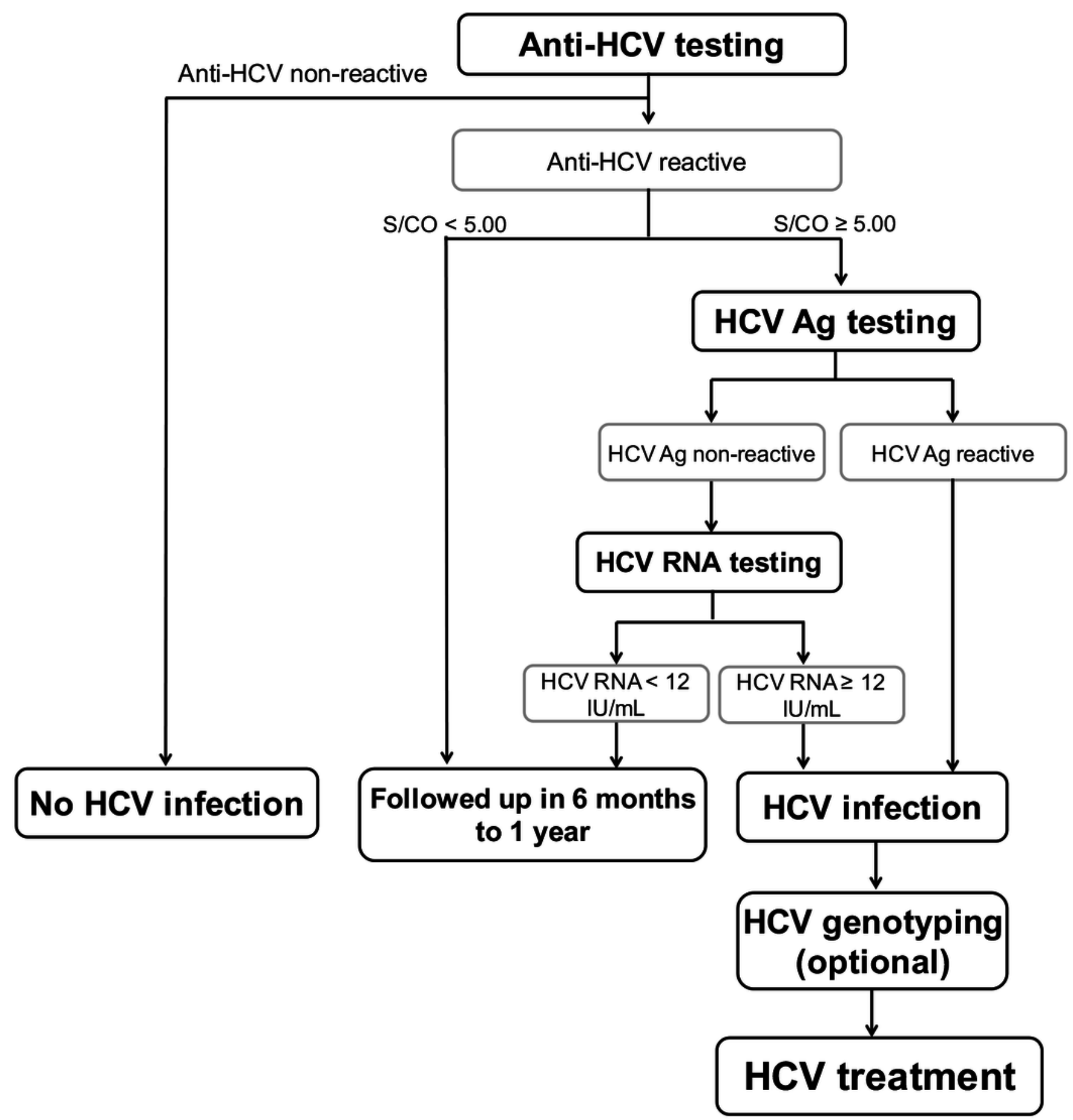

